\title{
Spatiality of ethnic identity and construction of sociopolitical interaction in South Sudan
}

\author{
Kon K. Madut \\ University of Ottawa, Canada
}

This article explores the complexity of the spatial construction of ethnicity, identity, and sociopolitical interaction among South Sudanese ethnic groups. The article focuses on the interplay between social interaction and the construction of ethnic identity as they affect the notion of human interaction and welfare. The narratives are based on the political sociology of South Sudan after its independence from Sudan and challenges endured in the process of sociopolitical transformation towards the reconstruction of national identity and peaceful coexistence. This discourse gives meaning to visible and invisible ethno-cultural constructions that shaped the norms of social and political interactions among various ethnic groups in the country. The analysis concluded that South Sudan society is socially, politically, and culturally constructed along ethnicized communities with variant perceptions of group and regional identities based on both primordial ties and instrumentalists' perceptions. These unique characteristics of spaces and construction of social structure has created multifaceted challenges in the process of social, economic and political reconstruction after the independent of South Sudan in July 2011.

Key Words: Space, social construction, identity, ethnicity, nationhood, society, coexistence.

Article Info: Received: June 14, 2017; Revised: November 10, 2017, Accepted: November 15, 2017; Online: November 25, 2017.

\section{Spatial organization of people and region}

Sociologist Emile Durkheim (1938) has observed that in all human societies, a transition from ethnocentric society or 'mechanical society to a more of civic society, or organic society' can be only realized with a complete transformation into an industrialized economy with more specialized division of labour and

* Correspondence address

Address: 75 Laurier Avenue East, Ottawa ON K1N 6N5, Canada.

Phone: +613-562-5700|Email: Kmadut@uottawa.ca

(C)2017 Human Geographies; The authors

(c) (1) This work is licensed under a

Creative Commons Attribution 4.0 International License. DOI:10.5719/hgeo.2017.112.4 
higher freedom of social and political consciousness (pp. 247-249). This includes the establishment of institutions, the rule of law, and moral guidance as an alternative moral value to cultural and ethnic norms. To better understand these concepts within the context of South Sudan, the analysis will start with (A) characteristics of people and (B) regional narratives that shaped the current construction of socioeconomic and spatial organisation of the South Sudanese society.

\section{Spatial organization of people}

South Sudan is home to about 64 different ethnic groups; the actual number of groups is not accurately recorded (Nyaba, 1997). There has been an ongoing dispute about the accuracy and reliability of the statistical data that reflects an accurate size of the population in the country due to political unrest and the central government's biased politics of marginalisation since the independence of Sudan in 1956. Therefore, data gathered under the central government before the independence in 2011 were not considered accurate or reliable. The assumption was that data collected before independence were not meant for any strategic socio-political or economic development in South Sudan. The central government's emphasis before independence was on social engineering and reconstruction of peoples' cultures and communities through introduction of the Arabic language and Islam. As such, the South Sudanese authorities have had disputes regarding the reported data not reflecting the exact number of people and their characteristics (NBOSS, 2015).

Since the independence of Sudan in 1956 to the signing of the Comprehensive Peace Agreement (CPA) in 2005, effective government policies were measured by the level of adoption of Arabization, Islamization, and cultural assimilation, regardless of social and economic outcomes or community well-being. The first census that included South Sudanese for the first time in Sudan was the Fifth Census of Population and Housing (FCPH) conducted in 2008. Its results were announced unilaterally by the central government in Khartoum and rejected by the Government of South Sudan (NBOSS, 2015).

The named census sets the number of people in South Sudan at 8,260,490 about 21 percent of the national average. The census also recorded that about 520,000 of South Sudanese population were living in the North Sudan, currently Sudan (NBOSS, 2015). The mentioned census has also revealed a population growth from 5,329,267 in 1983, to 8,260,490 in 2008. There was no reference to the displaced refugees and South Sudanese migrants in surrounding countries or abroad (e.g., Europe, United States, Canada, and Australia).

Nonetheless, the 67 percent indicator of population growth in the country (Sudan) from 1993 to 2008 has not been reflected on census result of 2008 in Southern Sudan to support the projected percentage of population growth. For example, unlike Southern Sudan, the population of Darfur reportedly increased from about 3 million in 1993 to 7.2 million in 2008, a projection that made South Sudanese dispute and question the authenticity of the results of the Fifth Census of Population and Housing (FCPH) of 2008 in Sudan (NBOSS, 2015). However, regardless of the disputed numbers and conflicting views on the 


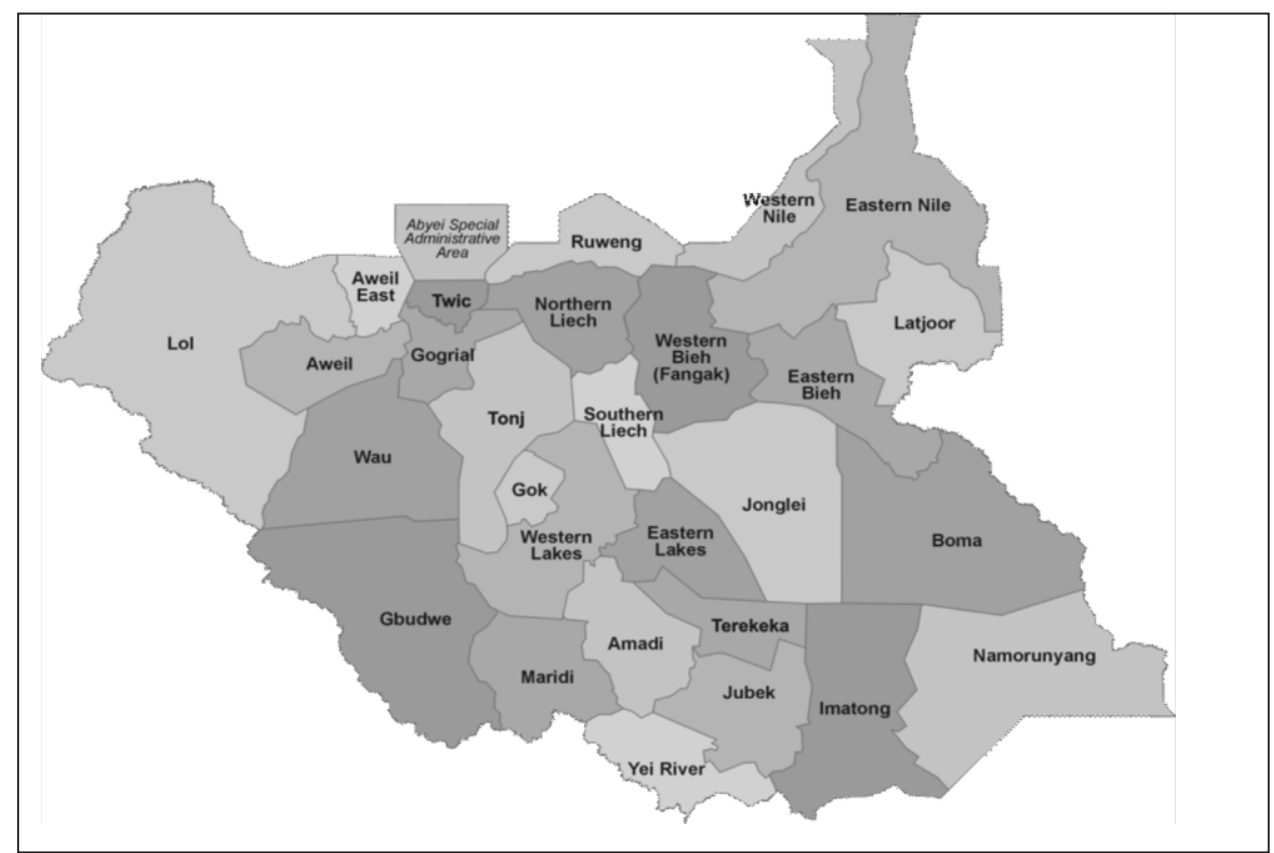

Figure 1. Map of the 28 states of South Sudan

Source: Wikipedia, States of South Sudan

projection of population in South Sudan, it is imperative that the Government of South Sudan conduct its own census to obtain an accurate projection of its population, for allocation of better services, equitable distribution of resources, and power-sharing. Figure 1 illustrates the 28 South Sudan's states within their perspectives' regions.

\section{Spatial structure of regions}

South Sudanese society can be clustered into three main regional groups with unique sociocultural, political, and economic characteristics. These regions are as follows.

(1) The Bahr el Ghazal: located in northwest South Sudan, the Bahr el Ghazal region was divided into four major areas because of administrative, socioeconomic, environmental, and cultural characteristics of the regions and its people. In 2010, four regions were enacted as political and administrative states. The Northern Bahr el Ghazal (NBG) region has a population of about 820,834, composed mainly of the Dinka and Luo ethnic groups. Second, the Western Bahr el Ghazal (WBG) has a population of about 358,692; it is the least populated and the most diverse in the region. WBG is inhabited by Aja, BalandaBoor (Luo), Balanda-Bviri, Banda, Bongo, Feroghe, Gollo, (Luo), Ndogo, Ngulngule, Sere, Shatt, Yulu, Kara, Binga, Indri, and Mangayat ethnic groups. Third, the Lakes region has a population of 782,504, comprised mainly of the Dinka ethnic group, Atout (Reel), and Jur (Beli \& Modo). The fourth region is Warrap region/state with a population of about $1,044,217$, comprised mainly of 


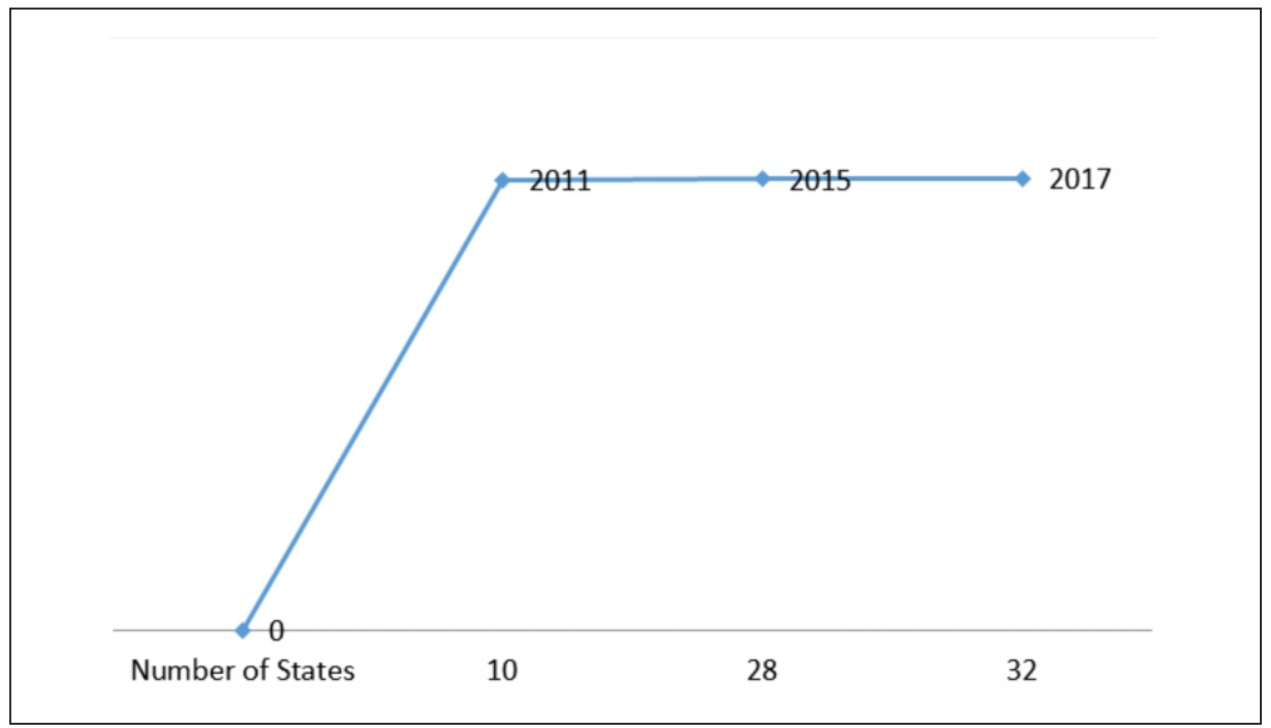

Figure 2. Trajectory of State Creation in South Sudan 2011-2017

the Dinkas and Bongo ethnic groups (Madut, 2015; Gurtong, 2017). The Bahr el Ghazal region hosts 21 ethnic groups, about $32 \%$ of the country's ethnic groups. On October 2nd, 2015, South Sudan's President (Salva Kirr Mayardit) has dissolved the regional 10 states and created 28 new states, thereby increasing the number of states in Baher el Ghazal to 10 states (Aljazeera, 2015). The newly created states include Wau State, Aweil State, Lol State, Aweil East State, Twic State, Gogrial East State, Tonj State, Eastern Lake State, Gok State and Western Lake State (figure 1).

(2) The Equatoria: The Equatoria region is located in the southern part of South Sudan and divided into three regions adopted as main states of the Equatoria region. These states were later divided into several political and administrative states of Western Equatoria with a total population of about 658,863 - Central Equatoria with a population of about 1,193,130 and Eastern Equatoria with a total population of about 962,719. It is worth noting that Juba in Central Equatoria has served as South Sudan's headquarters from 1976-1983 and was adopted as the capital for newly independent South Sudan (Madut 2015; Gurtong 2017). The Equatoria region is host to the ethnic groups of Adio (Makaraka), Acholi, Avukaya, Azande, Bai, Baka, Bari, Dongotona, Didinga, Ifoto, Kakwa, Lokoya, Lopit, Lotuka (Otuho), Larim (Boya), Kuku, Lango, Logir, Lulubo, Madi, Moro, Mundari, Pari, Pojulu, Nyangwara, Suri (Kachipo), Toposa, Imatong, Keliku, Lugbwara, Moru Mundu, Nyangatom, Tenet, Tid, and Woro. The Equatoria region hosts 35 ethnic groups, about $55 \%$ of the total ethnic groups in the country (Madut, 2015; Gurtong, 2017). It is worth noting that the 28 newly created states have also increased the number of states in Equatoria. These newly created states in Equatoria include Imatong State, Namorunyang State, Maridi State, Amadi State, Gbudwe State, Jubek State, Terekeka State and Yei River State (Figure 1). The number of these states has increased to 9 states by January 14th, 2017 (Sudan Tribune, 2017).

(3) The Upper Nile: The Upper Nile region is located in northern and eastern 
South Sudan, and is divided into three main regions that are also adopted as political and administrative states before and after the independence of South Sudan. These regions consist of the Jonglei state with a total population of $1,443,500$. According to the 2008 census, the Jonglei region is the largest and the most populous in the country, followed by the Upper Nile State with a total population of 1,013,629 and the Unity state with a total population of about 645,465 . The Upper Nile region hosts only eight ethnic groups of Murle, Nuer (Naath), Dinka, Shilluk (Chollo), Anyuak (Anyuaa), Jiye, Maban, and Uduk-about $13 \%$ of the total ethnic groups in the country (Madut, 2015; Gurtong, 2017). Figure 2 shows the trajectories of the states' creation in South Sudan from 2011 to 2017.

As in the case of all regions of South Sudan, the continuation of divisions and creation of new political-administrative states has also increased a number of states in the Upper Nile to about 10 states in 2015 and 13 states by January 2017. This includes Northern Liech State, Southern Liech State, Ruweng State, Eastern Nile State, Jonglei State, Western Nile State, Western Bieh State, Eastern Bieh State, Latjor State and Boma State (Figure 1). This was a result of increased enacted by presidential decree In January 14th, 2017, which granted 3 more states to the Upper Nile Region and 1 to the Equatoria Region thereby bringing the total number to 32 states (Sudan Tribune, 2017).

\section{Theoretical perspectives}

This narrative employs the social constructionist assumption that looks at race or ethnicity as a social construct dependent on mutual agreement and consent, mostly by the prevailing groups in society. This collective agreement is eventually accepted as a social norm to create a stratification of persons that subsequently determines limitations to power, such as economic or political power. Berg argued that 'what people do, how they act and structure their daily lives, and even how people are influenced by certain ideological stances can all be observed in traces people either purposely or unintentionally leave behind' (Berg, 1989). Similarly, Berger and Luckman suggested that 'the sociology of knowledge' created by people's day-to-day constructions of reality gives shape to the fabric of society (Berger \& Thomas, 1966). Thomas stated that if people accept a given situation as real, it becomes real for them (Berger \& Thomas, 1966).

As for the concept of race and how it relates to social interaction, Roy argues that the concept of '...race was created mainly by Anglo-European, especially English societies in the sixteenth and nineteenth centuries', and continues as a useful means of defining human communities based on socio-cultural, ethnic, region, or religious background (Roy, 2001). Within this debate of race and racial classification, Durkheim (1938) viewed the concept of race as a 'social fact' (p.13) that human societies need to understand and deal with accordingly, while Max Weber argued that race is only the adoption of the social practice of marrying members of the same clan, people, or another kinship group (endogamy) (Max, 1978). In this context, cultural anthropologist Emanuel Lusca stated that human societies are often socially constructed as groups, defined by either race or 
colour of skin, in which people become known as White, Asian, Mexican, Arab, Black, minority, etc. Such social constructions impact how a group is seen by others and thereby affects individuals' lives and their social, political, and economic interaction with others. In the same vein, Foucault (1991) added that '...potential harm in racial-ethnic categorization outweighs any potential for remedy' (p. 215). Gracia (2005) argues that 'grouping persons by race, ethnicity, or nationality' is always inappropriate and usually motivated by 'social conflict and abuses' (p. 1). Gracia's argument has been depicted within several dimensions of socio-political and ethnic groups' interactions in South Sudan as having hindered the progress of the nation's building.

In South Sudan, people construct social interaction and political participation based on ethnicity, tribes, and regional grouping. Most of the prior research that discussed socio-economic and political issues among these groups, reported significant social issues such as difficulties in creating peaceful co-existence, and lack of interest in the process of nation-building socially, politically, and economically.

The use of ethnicity as a factor in shaping social policy and equitable contribution remains a common practice throughout South Sudanese society. This discourse of ethnic categorisation, found in the classification of ethno-tribal grouping, prompted a review of the historical development of ethnonationalism and ethnic grouping in South Sudan society and what has been done to achieve a mutually agreed upon national identity after its independence from Sudan. Social constructionists' views on the construction of race and ethnicity highlight social facts that held South Sudanese society together for decades and shaped their common identity before its independence in 2011. Hence, this discourse can be further used in conceptualising and understanding the path to a reconstruction of meaningful ethnic relations, an inclusive national identity, power sharing, and peaceful coexistence. The concepts of race and ethnicity are discussed from both primordial and instrumentalists' perspectives for the purpose of categorization and analysis.

\section{Spatial construction of political identity}

The contemporary South Sudanese' identity was shaped by a shared history of the struggle to survive and preserve culture from the eras of slavery with TurkoEgyptians in 1822, colonialism under British and Egyptian rule in 1899, to the era of Arabization and Islamization employed by central governments after the independence of Sudan in 1956 (Mohamed, 1984). Historically, South Sudanese of African descent have made several attempts during these foreign interferences to preserve their ethno-cultural and tribal identities (Ole, 2012). One of the earliest examples is the rebellion of the Nuer and Azande ethnic groups against the colonial rule, which resulted in the assassination of British officers and Governor of Bahr El Ghazal in 1901(Shaw, 1987).

In 1930, the Colonial rule acknowledged South Sudan as an ethnically and culturally distinct society, and therefore ought to be treated accordingly (Deng, 1987). By 1940, this concept led to the total elimination of Arab influence and interests in South Sudan (Khalid, 1990). This paradigm shifts in the colonial 
politics and policies had lasted to 1946 when it was finally revised because of the growing Arab influence in the North and resistance against colonial policies towards South Sudan (Deng, 1987). However, South Sudanese continued to think of several options to gain an autonomous self-rule as manifested in the Juba Conference in 1947, which aimed to discuss the fate of South Sudan between unity and separation, the formation of a Liberal Party in 1955 with a call for federation in Sudan, Torit resistance, the Anya-Nya movement in 1963, and the SPLM movement that led to the final settlement and successful independence of South Sudan on July 9th, 2011 after decades of war (Markakis, 1987). However, the separation of South Sudan itself did not put an end to internal ethno-tribal clashes or external border conflicts with the now Sudan. There are still several unresolved post-independence tensions such as border demarcation and all of the pending security arrangements (Johnson, 2016).

These unresolved political issues between the two countries remained one of the challenges faced by the newly created state, coupled with internal socioeconomic and political problems which can also be better classified as bio-products of the past civil wars. To date, South Sudan continues to experience cycles of violence in the form of political grievances, ethnic rivalry, distrust between the government and the people, an undisciplined national army, armed militias, inter-communal violence, and grave human rights issues. This condition has earned South Sudan a top place on the classification of the world's failed and fragile states index (The Book, 2015).

In its core, the country adopted an ethnocentric approach in governance after its independence in 2011, which has weakened the political party and bureaucratic functions. The ethnocentric approach in governance has also created multi-faceted challenges and problems, such as corruption, lack of the rule of law, violation of human rights, ethnic exclusions, and ineffective mechanisms of conflict resolution and prevention (Kymlicka, 2004). Many affected groups are the minority ethnic groups within the Upper Nile, Equatoria, and Bahr el Ghazal Regions regardless of its re-division into several states. Further, due to lack of national cohesion, public and private institutions are ethnically dominated. This includes the ruling political party, the Sudanese People Liberation Armed Movement (SPLM), and the arm forces which are overrepresented by the ethnic Dinka, and allied None-Dinka minority tribes (Nyaba, 1997).

The construction of the current systemic domination has been shaped as a result of ethnic composition, tribal contributions, and alliances with the movement during the civil war between the SPLA and the central government in Khartoum between 1983-2005 (Hutchinson \& Jok, 2002). Other minority ethnic groups that were used by Khartoum in counter-insurgency against the SPLM have also managed to join the government through negotiated peace settlements after the independent of South Sudan. Some ethnic minority groups who have totally rejected the new SPLM system have either formed opposition parties or taken up arms against the government in Juba (Nyaba, 1997).

These historical synopses of social and political events illustrate a background on geopolitical factors that fostered unity of purpose and constructed a common identity adopted by mostly all indigenous African Christians who are currently known as South Sudanese. However, among the South Sudanese, the socialisa- 
tion and perception of identity are chapped by an individual and group ethnicity followed by the region of the inhabitant. These spatially structured identities have been evident in the construction that shaped the dynamic of social and political interaction as observed in political power-sharing and ethno-tribal conflicts in the contemporary South Sudan.

\section{Spatial organization of power and politics}

According to Herwitz (1986), in deeply divided societies like South Sudan, the interests and demands of communal and warring groups can be accommodated only by the establishment of a meaningful power-sharing (pp. 85-101). Otherwise, such deep societal divisions would continue to pose multifaceted problems for democracy and socioeconomic development in the country as observed shortly after the independence of South Sudan. It is even more difficult to establish and maintain a democratic government in divided societies than in homogeneous countries (Herwitz, 1986). The practices of genuine power sharing have proven to be an effective democratic approach with a better chance of being successful in divided societies to mitigate political, social, and economic issues. The cases of power-sharing approaches applied prior to the 1960s, as well as the ones adopted in the recent cases of divided societies such as Belgium, Bosnia, Czechoslovakia, Northern Ireland, and South Africa, have shown some success (Simeaon \& Conway, 2001).

Adoption of power-sharing and equitable representation of cultural, ethnic, and religious groups would have also benefited South Sudan if mutually agreed upon as an alternative system of governance in the country. However, the SPLM's first ruling party in South Sudan has adopted a system of majority-rule with over-representation of the ethnic Dinkas (ethnic-majority) in the executive followed by the ethnic Nuers (the second majority).

The concept of power-sharing, in this case, was focused on Dinka-Nuer ethnic groups who are considered tribes of the majority and the accommodation of other ethnic allies to form the first national government right after the independence in July 2011. At its core, it almost resembles Belgium's constitutional requirement that cabinet and executive be composed of equal numbers of the two major ethnolinguistic groups of Dutch and French (Hooghe, 1991). Such a concept of power sharing was repeated again in the last signed peace agreement for resolution of conflict in South Sudan (ARCSS) in August 2015, of which ethnic political elite have compromised on preserving the post of presidency to the tribe of majority (the Dinka), and the vice presidency to the second tribe of majority (the Nuer) as a baseline for implementation of the signed agreement (ARCSS) (Gurtong, 2017).

Even so, the Dinka elders and political elites' had reservations about the contents of the agreement and therefore considered it a threat to their future political and economic ambition in the country. Consequently, the agreement did not last and a second fight broke out in 2015, killing about 7000 soldiers from both sides and ending with the removal of the vice president who escaped on foot to Central Africa (Rolandsen, 2015). The model of power-sharing between Dinka-Nuer had some socioeconomic and political marginalisation to 
the rest of the excluded 62 ethnic groups in South Sudan. Therefore, a call for federalism by the SPLM-IO led by the Vice President Riek Machar (a Nuer) has been welcomed by minority ethnic groups who started to join the movement and promoted his ideas of political and conflict resolution in South Sudan (Radio Tamazuj, 2014).

Spatially, South Sudan is a deeply divided society - ethnically, culturally, socially, politically, and regionally. According to Hale (2004), in such divided societies with geographically concentrated communal groups, a federal system is undoubtedly an excellent way to provide a sense of autonomy for these groups.

Politically, federalism is an effective system in which minority groups within the federation can be even overrepresented in some cases like, the United States Senate, which gives two seats to Wyoming, a small state, compared with the massive California, which is allocated the same number of seats (Stein, 2008). These can be characterised as a weakness of federalism because overrepresentation of smaller units in the federal chamber violates the democratic principle of one person, one vote (Bieber \& Wolff, 2005). In the case of South Sudan, the power-sharing models of Germany and India can be more desirable than that of the federalism of the United States, Switzerland and Australia.

In this context, Horowitz (2002) recommended that the federation would be decentralised with small states or provinces to increase the prospects of homogeneity and to reduce prospects of domination by large states on the federal level. In short, the complexity of spatial organization and structure of ethnicity, as well as social relations, make progress towards socioe-conomic and political development challenging. These were clearly evident in the process of socio-political development and nation-building in South Sudan.

\section{Spatial structure of ethnicity and interactions}

Historically, Sudanese elites have relied heavily on primordial ties as the basis for defining the national character. Before independence, South Sudanese elites have used an instrumentalist (Muslims Arab in the North vs Christian African in the South) approach in defining South Sudanese identity throughout the history of social and political development. This concept of divide and conquer has been used by the political elite in Sudan as a basis for ethnic, religious, and political manipulation and rallying to gain access to socioeconomic and political power (Deng, 1995).

In many cases, ethno-political elites capitalise on the fact that individuals from different groups dislike 'mixing' across ethnic lines, a human quality that always hinders collective of socioeconomic outcomes prospects of nation building, especially in a multiethnic society (Vigdor, 2001). It has also been observed that individuals prefer to contribute in public projects that benefit their own ethnic group; therefore, ethnic elites tend to treat public institutions as an ethnic-owned organisation that can be manipulated and controlled to serve the interests of the ethnic elite(s) in power (Vigdor, 2001). However, social scientists do not seem to find better theories that accurately explain where ethnic consciousness comes from and how it affects individuals' taste and differences (Vigdor, 2001). 
In the case of South Sudan, some argued that it was because of the systemic policies of assimilation and divide-and-rule introduced by colonials' regimes and later by Arabized Muslims rulers in Sudan after its independence. For these reasons, South Sudanese continuously sought a locally constructed identity that linked a person or group to ethnic groups, tribes, and regions of origins (Eriksen, 1999). Consequently, they become to be known as South Sudanese, a constructed identity that was often used as a political means of resisting colonialization and preservation of ethnic identity for decades. According to Grimes (1996), the majority of people in South Sudan are classified as Nilotics or Nilo-Saharan; only a few identify themselves as Bantus. In this narrative of ethnicity and tribal grouping in South Sudan, anthropologists and biologists think that Nilo-Saharan ethnic groups are biologically related by race and ethnic linkages, an assumption that is yet to be further confirmed in the era of advanced DNA tests (Grimes, 1996).

\section{Ethnic distributions and representation}

The means of ethnic distribution in South Sudan comprise 64 groups in total. The percentages were calculated by dividing the number of groups in each region by the sample size (64) as in the following:

A. The Equatoria Region accommodates 36\% / $64=56 \%$ of total ethnic groups in the country.

B. The Bahr el Ghazal Region accommodates $21 \% / 64=32 \%$ of the total ethnic groups.

C. The Upper Nile Region accommodates $8 \% / 64=13 \%$ of the total ethnic groups in the country.

In the Equatoria Region where about $55 \%$ live, ethnic groups have managed to re-construct ethnic identities based on a cluster of regional identities to be known as Equatorian rather than an ethnicity of particulars or spaces of origin. As such, many people, including local South Sudanese citizens, have sometimes mistaken this regional identity Equatorians for a tribe, rather than a region. In short, unlike other regions, the concept of Equatorians as an identity is based on a cluster of 36 regional ethnic groups. The same concept of clustering is successfully adopted among groups known as Fertit in Bahr El Ghazal, a cluster of 14 ethnic groups who have managed to socially, culturally, and politically adopt a communally constructed identity to be known as 'Fertits' rather than being known by their tribes of origins.

The Greater Equatoria Region hosts the majority of the ethnic groups in South Sudan and has had a better management of peaceful co-existence through a mutually agreed upon socially constructed sense of identity that linked groups to the region rather than the ethnicity of particulars. The Bahr el Ghazal came as second as far as ethnic diversity is concerned. The Bahr el Ghazal Region is also a host of the majority of the Dinka ethnic group population in South Sudan. The Upper Nile hosts eight ethnic groups and is known as a home to the majority of the Nuer ethnic group population. Even so, the 
Upper Nile Region is the most affected region with the everlasting ethnic feuds and challenges of peaceful co-existence among various ethnic and tribal groups (Human Rights Watch, 1999).

In this context, Miguel and Gugerty (2005) agreed that it is often 'difficult to sustain cooperation across ethnic groups in areas where members of different groups tend not to have frequent social interactions or personal affinity'. In this context, enacting public policies that encourage social interaction, power and information sharing, and coordination across groups can help rebuild ethnic bias, preferences and grievances associated with diversity (Miguel \& Gugerty, 2005).

Regardless of research limitation on types of public policies that promote inclusion and reduce division, many experts agreed that institutional reform through promotion of power-sharing across groups as well as within government organizations would be an ideal approach of equitable ethnic representations (Byman, 2002), simply because the minority groups are granted minimum representation in government and voice over policies that may affect change over their space and place. Practically, it is worth noting that power-sharing structures may create competition among ethnic groups in the political space and institutionalises divisions across groups rather than promoting coexistence (Byman, 2002). Consequently, it may hinder the construction of new national identity or multiethnic political coalitions with a universal platform that cut across ethnic places and spaces.

\section{Spatiality of social and political interaction}

The inter-ethnic, tribal sociopolitical and cultural constructions vary within the three main regions of South Sudan, which are Bahr el Ghazal, Equatoria, and Upper Nile regions. The ethnic and tribal communities within the Equatoria region were able to construct an ethno-group identity under a unified regional identity to be known as 'Eguatorian' rather than tribes of particulars. The dynamic of ethnic relations and political interaction in Equatoria is by far an exceptional model of ethnic clustering found within South Sudanese society. The same concept of clustering also found among the Fertit groups in Western Bahr El Ghazal, a cluster of groups of tribes who have managed to socially, culturally, and politically reconstruct an identity to be known as Fertit rather than tribes of origins (Madut, 2015). The process of reconstruction of ethnotribal identities and adoption of an inclusive national identity remained a major challenge in South Sudan. Ethnocentrism and its effect has so far remained the main factor that hinders socio-economic and political development in the newly created state. Ethnicity and tribal affiliation have always been cited as an underlying cause of several inter-ethnic and political conflicts locally and at the national levels right after the independence in 2011 (UNMISS, 2014).

Nonetheless, these cycles of conflicts regardless of causes are later adopted as life-style, group culture and livelihood within groups who are trapped in historical cycles of revenge. These historical ethnic feuds were later transformed and understood as political rivalry in the quest for ethnic power and socioeconomic domination. 
In South Sudan, an outcome of political mobilisation and participation is influenced by tribal and ethnic contribution, i.e., political elites within tribes of the majority manipulating or determining the outcomes of political representation and economic opportunity of the minority ethnic groups in the country.

As such, the Dinka ethnic groups insist on controlling all aspects of sociopolitical and economic institutions in the country because they represent the highest number of a single ethnic group with a population of 1.5 Million. The Dinkas are found in both Bahr el Ghazal and Upper Nile regions. The Nuer ethnic group is the second largest ethnic group with 800,000 of its population living in the Upper Nile region, followed by the Luo Shilluk, the third largest ethnic group (Gurtong, 2017; Madut, 2015).

The Equatoria ethnic groups often rally for the interest of their region by pursuing political and economic opportunity under the cluster of Equatorian rather than ethnic affiliation or tribal affiliation as found in the Upper Nile and Bahr el Ghazal. Historically, this socially constructed identity (Equatorian) has played a great role in shaping socio-political and economic development and minimised ethnic tensions in the region and South Sudan in general from 1956 to 2011(Crisis Group, 2016).

\section{Conclusion and policy implications}

The independence of South Sudan was perceived by the majority of South Sudanese in the country and abroad as the end of a long-lasting war with the North (Sudan) and beginning of new era of peace, reconciliations, and socioeconomic development. The shared history of marginalisation and brutality coupled with the quest for national and religious identity has paved the way to the endorsement of Separation, in which $99 \%$ of South Sudanese voted to have a separate country (United States Institute of Peace, 2017). Unfortunately, the current SPLA/M ruling party have failed to capitalise on people's desires' and became instead preoccupied with internal power struggles and redefinitions of the goals and objectives of the movement (Nyaba, 2016). The SPLM/A leadership should have promoted dialogue and interaction among the leaders of distinct ethnic communities who are better able to coordinate responses to violations of intergroup cooperation and equally contribute in the process of nation-building. In their study, 'Explaining inter-group corporation', Fearon and Laitin (1996) asserted that group leaders are capable of punishing violators from within their own ethnic group through the so-called '...in-group policing'. This approach was effectively utilised during the colonial period in Sudan, especially in the process of social control, conflict resolution, and taxation. The colonial administration and the subsequent governments in Khartoum have been dependent on traditional ethnic chiefs in all aspects of communal, political, and economical administration (Badal, 2005).

This approach has been undermined by the SPLM/A rule, which instead empowered ethnic SPLA generals and favoured them over their traditional ethnic leaders (Badal, 2006; Leonardi et al., 2005). Indeed, respect for traditional rule and cooperation from ethnic elite is in many cases an attestation of better ethnic relations; however, it is difficult to link how such cooperation 
affects relations between groups and individuals (Miguel, 2004). Even so, South Sudan does not lack ethnic coordination among ethnic elites, but the nation is also challenged with the problem of national identity and language. Drawing from Tanzania's experience, the potential for ethnic conflict and politics has been reduced by the universal use of the Kiswahili language, which replaced English as the official language in the 1960s. After its independence in 1962, the Tanzanian regime adapted Swahili as the working language in government administration and established the National Swahili Council to promote its use in all public spaces and across places (Miguel, 2004). Kiswahili is an indigenous African language originating on the Indian Ocean coast of East Africa and is seen as largely ethnically neutral in both countries. Kiswahili was also spoken in Kenya for decades; however, it was not applied in the national project as in the case of Tanzania and been used in an official setting along English and Kikuyu (Miguel, 2004). Rather, after its independence, Kenya has adopted similar ethno-tribal politics of South Sudan and therefore developed into a different model of ethnic politics than that of Tanzania.

In short, the everlasting war of identity, economic, and political marginalisation was brought to an end by signing of the Comprehensive Peace Agreement (CPA) in 2006. However, the independence of South Sudan did not address the core reasons of rebellion against the central government in Khartoum such as ethnocentric politics of marginalisation, equitable distribution of wealth, and socio-economic and political development across the regions. In addition, the newly created state has failed to preserve the unity of purpose developed during the war against the regime in then-Sudan and is unable to reconstruct coherent national identity and promote a national language that can be adopted by the 64 ethnic groups in the country.

Most political and technical contributions yielded little in terms of moving South Sudan towards a viable nation-state with sustainable social and political institutions. This is because of the unresolved history of ethnic rivalry and the rise of ethnic nationalism in public and political institutions. The style of governance and political systems in South Sudan are built on ethnonationalism and representation of tribal alliances that cannot be sustained. Most important is the lack of coordination among the ethnic elite and their willingness to promote peaceful coexistence among various ethnic groups. For a way forward, this entails sensitivity to equity and inclusions in all aspects of socio-economic and political participation in the country, regardless of ethnic or regional affiliation. Nonetheless, it is important that the ethnic elites find ways of establishing venues of rebuilding trust and working for a common national language that can be adopted as the official language of the country.

\section{References}

Aljazeera (2015), South Sudan president creates 28 new states, 16 July 2016, (https://goo.gl/jQj6LA).

Badal, R. (2005), Local traditional structures in Sudan, Uppsala, Life and Peace Institute.

Berg, L.B. (1989), Qualitative research methods for the social sciences, Needham 
Heights, Allyn and Bacon.

Berger, P.L. and Thomas, L. (1966), The social construction of reality, New York, Anchor Books.

Bieber, F. and Wolff, S. (2005), 'Introduction: Elections in divided societies", Ethnopolitics, vol. 4, no. 4, pp. 359-363.

Byman, D.L. (2002), Keeping the peace: Lasting solutions to ethnic conflict, Baltimore, MD, The Johns Hopkins University Press.

Crisis Group (2016), South Sudan's South: Conflict in Equatorias, 17 July 2016, (https://goo.gl/akWFeB)

Deng, F.M. (1995), War of visions, conflict of identities in the Sudan, Washington D.C., Brookings.

Deng, F.M. and Presser G. (1987), The search for peace and unity in the Sudan, Washington, D.C., The Wilson Center Press.

Durkheim, E. (1938), The rules of sociological method, New York, Free Press.

Eriksen, T.H. (1999), 'A Non-ethnic State for Africa?' in P. Yeros (ed) Ethnicity and Nationalism in Africa: Constructivist Reflections and Contemporary Politics, Basingstoke, Macmillan.

Fearon, J. and Laitin, D. (1996), 'Explaining interethnic cooperation', The American Political Science Review, vol. 90, no. 4, pp. 715-735.

Foucault, M. (1991), 'Governmentality in the Foucault effect: Studies in governmentality', in G. Burchell, G, Colin and P. Miller (eds), Chicago, University of Chicago Press.

Gracia, J.E. (2005), Surviving race, ethnicity, and nationality: A challenge for the twenty-first century, Oxford, Rowman \& Littlefield.

Grimes, J. (1996), Ethnologue language family index, 13th ed, 23 September 2016, (https://goo.gl/dtMyAE).

Gurtong (2017), Power-mapping of ethnicity in the Republic South Sudan, 24 September 2016, (https://goo.gl/F3NsZE).

Hale, H. (2004), 'Divided we stand: Institutional sources of ethno-federal state survival and collapse', World Politics, vol. 56, pp. 165-93.

Hooghe, L. (1991), A leap in the dark: Nationalist conflict and federal reform in Belgium, Ithaca, Cornell University Press.

Horowitz, D.L. (1986), 'Communal armed organizations', European Journal of Sociology / Archives Européennes De Sociologie / Europäisches Archiv Für Soziologie, vol. 27, no. 1, pp. 85-101, 23 September 2016, (https://goo.gl/SaQA69).

Hororwitz, D.L. (2002), 'Constitutional design: Proposals versus processes' in A. Reynolds A (ed), The architecture of democracy: Constitutional design, conflict management, and democracy, New York, Oxford University Press.

Human Rights Watch (1999), Famine in Sudan, 1998, The Human Rights Causes, New York, Human Rights Watch.

Hutchinson, S.E. and Jok, M.K. (2002), 'Gendered violence and the militarisation of ethnicity: A Case study from South Sudan' in R. Werbner R (ed), Postcolonial Subjectivities in Africa, London, Zed Books.

Johnson, D.H. (2016), Abyei: Sudan's West Bank. The Enough Project, 24 September 2016, (https://goo.gl/FgnokU).

Khalid, M. (1990), The government they deserve: The role of the elite in Sudan's political evolution, London, Kegan Paul.

Kymlicka, W. (2004), 'Nation-building and minority rights: Comparing Africa 
and the West' in B. Berman, D. Ayoh and W. Kymlicka (eds) Ethnicity and Democracy in Africa, Athens, Ohio University Press.

Leonardi, C. (2007), 'Violence, sacrifice, and chiefship in Central Equatoria, Southern Sudan', Africa, vol. 77, no. 4, pp. 535-558.

Madut, K. (2015), 'Institutional development, governance, and ethnic politics in South Sudan', Journal of Global Economy, vol. 3, pp. 147.

Markakis, J. (1987), National and class conflict in the horn of Africa, Cambridge, Cambridge University Press.

Max, W. (1978), Economy and society, Berkeley, University of California Press.

Mohamed, O.B. (1984), 'Ethnicity, regionalism, and the national cohesion in Sudan' in The Sudan: Ethnicity and national cohesion, Bayreuth Mrican Studies Series, Bayreuth, Bayreuth University.

Miguel, E. (2004), 'Tribe or Nation? Nation Building and Public Goods in Kenya versus Tanzania' World Politics, vol. 56, pp. 327-62.

Miguel, E. and Gugerty, M. (2005), 'Ethnic diversity, social sanctions, and public goods in Kenya', Journal of Public Economics, vol. 89, pp. 11-12.

NBOSS (2015), National Bureau of Statistics, Republic of South Sudan, 23 February 2015, (http://ssnbs.org/).

Nyaba, P. (1997), The politics of liberation in South Sudan, Kampala, Fountain Publisher.

Ole, F. (2012), 'Defining the nation in South Sudanese media discourse', Africa Spectrum, vol. 47, pp. 21-49.

Radio Tamazuj (2014), Equatoria governor: We stand for federalism. Radio Tamazuj, 23 February 2015, (https://goo.gl/EWYnCt).

Robertshaw, P. (1987), 'Prehistory in the Upper Nile Basin', The Journal of African History, vol. 28, pp. 177-189.

Rolandsen, H. (2015), 'Another civil war in South Sudan: The failure of guerrilla government?', Journal of Eastern African Studies, vol. 9, no. 1, pp. 163-174.

Roy, G. (2001), Making societies: The Historical Construction of our World, Thousand Oaks, Pine Forge Press.

Sudan Tribune (2017), South Sudanese President creates four more states, 23 February 2017, (https://goo.gl/1w7dp8).

Simeaon, R. and Conway, D. (2001), Federalism and the management of conflict in multinational societies in multinational democracies, New York, Cambridge University Press.

Stein, M. (2008), How the states got their shapes, New York, Harper.

The Book (2015), Fragile States Index, 29 February 2016, (https://goo.gl/Z52oGC).

UNMISS (2014), Conflict in South Sudan: A human rights report, 29 February 2016, (https://goo.gl/ehwYRP).

United States Institute of Peace (2017), Supporting a peaceful transition to an independent South Sudan, 12 February 2016, (https://goo.gl/ZUMN6x).

Vigdor, J. (2001), 'Community composition and collective action: Analyzing initial mail response to the 2000 Census' (unpublished manuscript), Fayetteville, NC. Duke University,

Worldmap (2017), Map of South Sudan, 12 February 2016, (https://goo.gl/oeg8V7).

World Population Review (2016), Population of South Sudan, 23 September 2016, (https://goo.gl/aA9yqD). 